\title{
The skull of young Mammuthus trogontherii (Pohlig, 1885) from the early Middle Pleistocene of the north-eastern Sea of Azov Region
}

\author{
Vera S. Baigusheva, Gennadiy G. Matishov \& Vadim V. Titov*
}

\begin{abstract}
Vera S. Baigusheva, Azov historical, archaeological and paleontological museum reserve, Moskovskaya str., 38/40, 346780, Azov, Russia; Gennadiy G. Matishov, Southern Scientific Centre RAS, Chekhov str., 41, 344006 Rostov-onDon, Russia [matishov_ssc-ras@ssc-ras.ru]; VadimV. Titov, Southern Scientific Centre RAS, Chekhov str., 41, 344006 Rostov-on-Don, Russia [vvtitov@yandex.ru]
\end{abstract}

\begin{abstract}
Incomplete skull of a young elephant with dP4 and a fragmentary tusk were found in the alluvial deposits exposed in a sand pit near the settlement of Kagalnik. The age of the enclosing deposits correlates with the early Middle Pleistocene, the time range of the Tiraspol faunal complex of the Eastern Europe (=Cromerian), and the regional rodent biochron MQR 5. Two skeletons of Mammuthus trogontherii have been previously found in this area. The dental structure of the studied specimen evidences its attribution to M. trogontherii and demonstrate its difference from other taxa of mammuthoid elephants. How to cite this article: Baigusheva V.S., Matishov G.G., Titov V.V. 2018. The skull of young Mammuthus trogontherii (Pohlig, 1885) from the early Middle Pleistocene of the north-eastern Sea of Azov Region // Russian J. Theriol. Vol.17. No.2. P.61-67. doi: 10.15298/rusjtheriol.17.2.01
\end{abstract}

KEY WORDS. Mammuthus, dental morphology, variability, early Middle Pleistocene, Russia.

\section{Череп молодой особи Mammuthus trogontherii (Pohlig, 1885) из нижнего неоплейстоцена Северо-Восточного Приазовья}

\author{
В.С. Байгушева, Г.Г. Матишов, В.В. Титов
}

\begin{abstract}
РЕЗЮМЕ. Из аллювиальной толщи, вскрытой в нескольких карьерах около пос. Кагальник, происходит находка неполного черепа молодой особи слона с зубами dP4 и обломком бивня. Вмещающие отложения датируются ранним средним плейстоценом (= ранним неоплейстоценом), временем существования тираспольского фаунистического комплекса Восточной Европы (= Кромер) и региональной зоной по грызунам MQR 5. Из этих карьеров известны находки двух скелетов Mammuthus trogontherii. Характеристики зубов позволяют отнести находку к M. trogontherii и показать её отличия от других таксонов мамонтоидных слонов.
\end{abstract}

КЛЮЧЕВЫЕ СЛОВА. Мammuthus, морфология зубов, изменчивость, ранний средний плейстоцен, Россия.

\section{Introduction}

The recent literature describing finds of Mammuthus trogontherii (Pohlig, 1885) from the vast areas of Eurasia is quite ample (Guenther, 1969; Palombo \& Ferretti, 2005; Lister \& Stuart, 2010 et al.). But the cranial and dental features of young animals of this species are insufficiently known. Guenther (1969) presented tables and graphic data showing a number of measurements in teeth of different replacement series for the abundant material from early Middle Pleistocene Süssenborn locality (Germany), including the features of deciduous teeth. Dubrovo (2001) described a specimen of dp4 from Early Pleistocene site of Untermassfeld (Germany) and for the purpose of comparison tabulated metrical characters of $\mathrm{dP} 3 / \mathrm{dp} 3-\mathrm{dP} 4 / \mathrm{dp} 4$ in throgontherine elephants. The remains of elephants with

* corresponding author
dP2-dP3 referred to $M$. trogontherii were also noted from the Early Pleistocene site of Shanshenmiaozui in China (Tong, 2012; Tong \& Chen, 2016). The dentition of $M$. trogontherii with incomplete $\mathrm{dP} 3-4$ and M2-M3 was described from late Middle Pleistocene Belchatów locality in Poland (Pawlowska et al., 2014). Yatsko (1948) reviewed dental characters of different replacement series in Elephas wüsti M. Pawlow ( $M$. trogontherii) from Pleistocene deposits of the Khadzhibey Estuary (vicinities of Odessa, Ukraine). The tooth fragment identified by the authors as dP4-M1 of $M$. trogontherii was mentioned from the Cromerian West Runton locality (Great Britain) (Lister \& Stuart, 2010). Garutt \& Foronova (1976) and Garutt (1977) published variability ranges of dental characters in several replacement series of throgontherine elephants.

In 2016, a fragmental skull of a young elephant was found in a sand pit on the north-eastern outskirts of the Kagalnik settlement near the Zeleniy village (Azov 


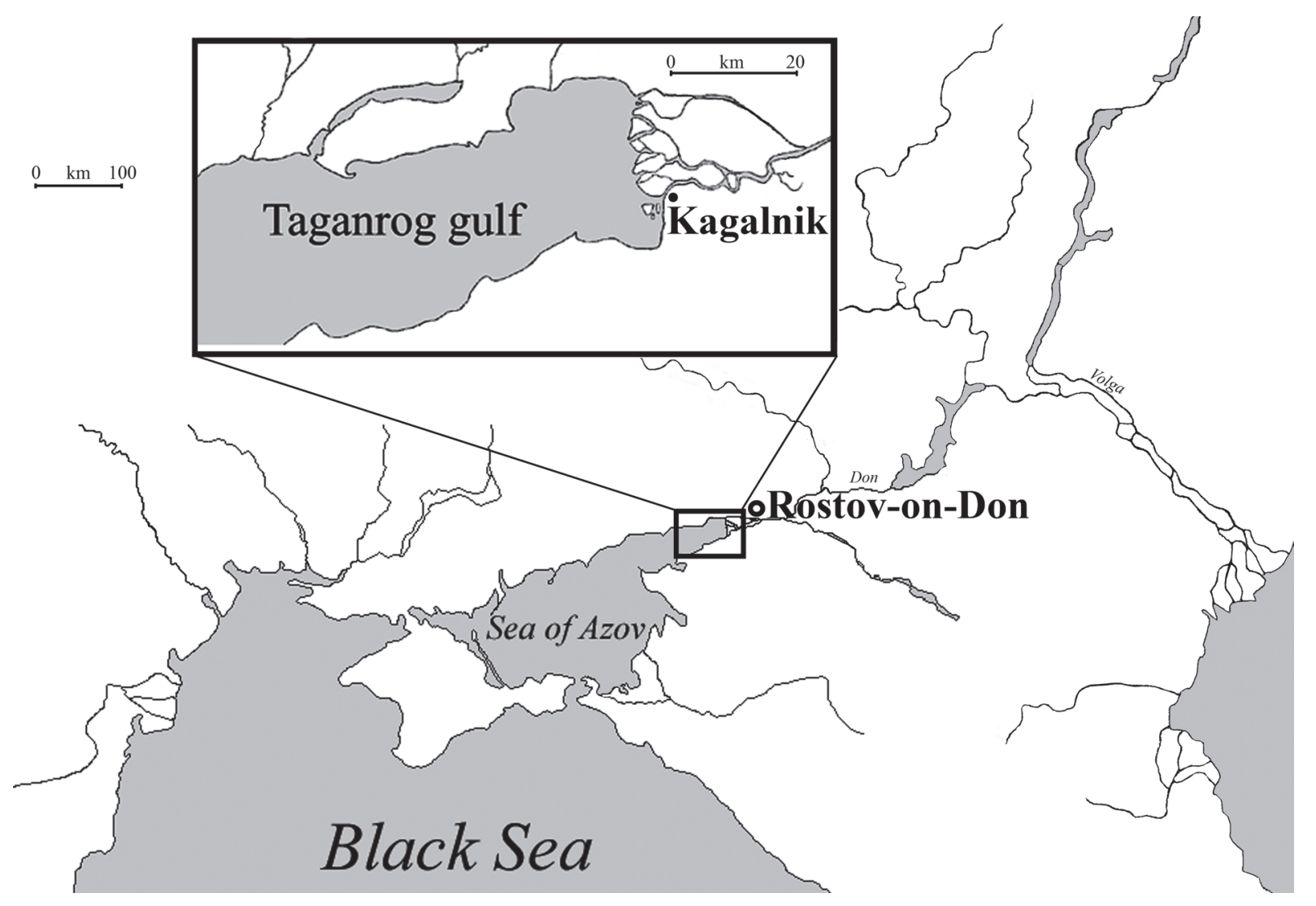

Fig. 1. The location of Kagalnik settlement (Azov district, Rostov Region, Russia).

region, Rostov district, Zeleniy locality; Fig. 1). Several working and abandoned sand pits aimed at the thick sequence of fluviatile sands dated to early Middle Pleistocene are available for the study near the settlement of Kagalnik. The generalised geological section includes basal sandy and loamy sequence of deltaic-lagoon origin overlain by subaerial deposits. Sandy deposits (15$20 \mathrm{~m}$ thick) are represented by light quartz sands with numerous shells of Viviparus, Dreissena, and other freshwater mollusks. They form the base of the socalled Vth Semibalki terrace of the left bank of the Don River valley spreading to the northeast from the mouth of the Kagalnik River (Lebedeva, 1972). The entire section of sandy sequence contains uniform assemblage of land of vertebrates and molluses indicating a relatively short period of its sedimentation (Tesakov et al., 2007; Quaternary ..., 2010). Molluscan and fish fauna from the sequence evidence a large fluviatile freshwater basin with backwaters and abandoned channels, and abundant riparian and water vegetation (Frolov \& Kurshakov, 2015). The mammalian assemblage includes Trogontherium cf. cuvieri, Microtus (Stenocranius) gregaloides, Microtus nivaloides, and Eolagurus argyropuloi, as well as Equus sp., Praemegaceros sp., Bison sp. This association, typical for the Tiraspol Faunal Complex (late Early Biharian, Galerian, Cromerian), is widely known from a number of localities dated at the beginning of the Middle Pleistocene and correlates with the regional micromammalian biochron MQR 5 (Tesakov et al., 2007; Quaternary ..., 2010). Old sand pits near Kagalnik (the Kagalnik locality) yielded two famous nearly complete skeletons of Mammuthus trogontherii in 1964 and 1998 (Baygusheva \& Garutt, 1987; Baygusheva \& Timonina 2001, Baygusheva et al., 2012) coming from loam bed in the upper part of the fluviatile sequence. The new specimen comes from a layer of inequigranular sands in the middle part of the same thickness.

\section{Material and methods}

An incomplete facial cranium of a young elephant with both preserved $\mathrm{dP} 4$ and partially erupted left M1 is catalogued in the collection of the Southern Scientific Center RAS, No. SSC K-1. The braincase is missing (Fig. 2). The distal parts of the tusk alveoli are not preserved. The left alveolus preserves the base of the tusk.

Dental measurements and indexes follow standard systems (Dubrovo, 1960; Maglio, 1973; Garutt \& Foronova, 1976). Measurements of the skull conforms to the methodology of Dubrovo (1960). The individual age was estimated based on the comparison of the averaged data on teeth replacement series in the extant elephant Loxodonta africana (Blumenbach, 1797) (Laws, 1966; Jachmann, 1988; Lee et al., 2012). 


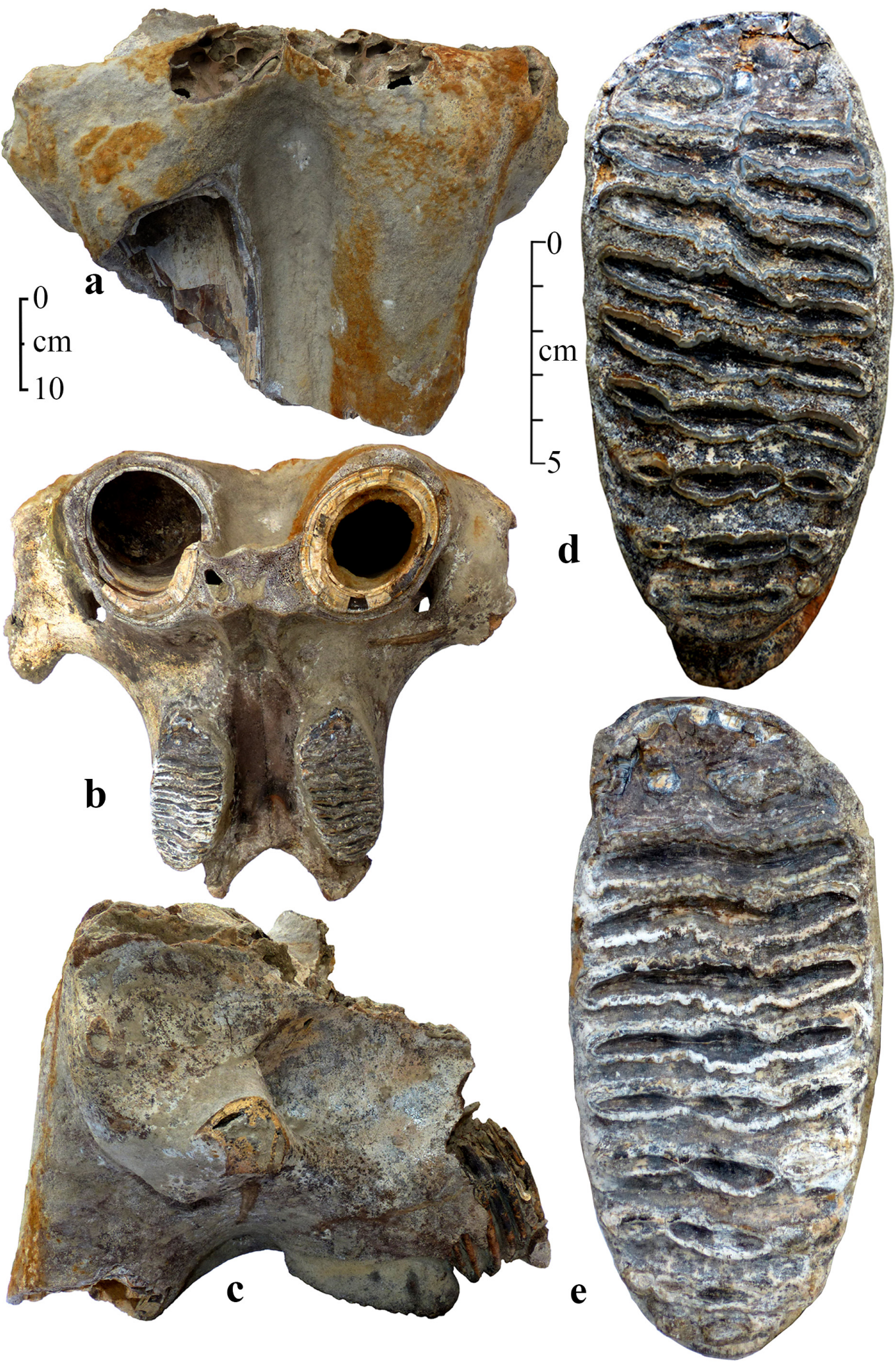

Fig. 2. Incomplete skull of Mammuthus trogontherii from Kagalnik (Zeleniy locality; North-Eastern Sea of Azov area, Russia). a - anterior view, b - ventral view, c - lateral view, d - upper left dP4, occlusal view, e - upper right dP4, occlusal view. 
Table 1. Measurements of the skull of Mammuthus trogontherii from Kagalnik village (collection No SSC RAS K-1; Zeleniy locality; North-Eastern Sea of Azov area, Russia).

\begin{tabular}{lc}
\hline \multicolumn{1}{c}{ Parameters } & Measurements, mm \\
\hline Width between supraorbital processes & 465.0 \\
The upper width of the intermaxillary bones at the level of the lower edge of the & 312.0 \\
infraorbital foramens & 76.0 \\
Width of interalveolar hollow at the upper level of tusks alveoli & 254.6 \\
Width between preorbital foramens & 205.4 \\
Width of upper jaw at level of dP4 posterior edges & 194.4 \\
Maximal width between dP4 outer edge & 53.8 \\
Internal width between anterior edges of dP4 (anterior width of bony palate) & 67.7 \\
The height of the right zygomatic arch in its anterior third & 83.8 \\
Width of the hoanal notch & 109.0 \\
Antero-posterior diameter of left tusk at the alveolus base & 93.5 \\
Lateral-medial diameter of left tusk at the alveolus base & 112.0 \\
Antero-posterior diameter of right alveolus base & 103.9 \\
Lateral-medial diameter of right alveolus base & \\
\hline
\end{tabular}

The attribution of the studied teeth to the replacement series was based on comparison with rich odontological collection of the related group of Early Pleistocene southern elephants Archidiskodon meridionalis gromovi Garutt et Alexeeva, 1965 from Liventsovka and Khapry localities, and A. m. tamanensis Dubrovo, 1964 from the Sinyaya Balka locality (Baigusheva et al., 2016a, b). The data on deciduous teeth of Mammuthus primigenius (Blumenbach, 1799) from Kostenki (Maschenko, 2002) were also used.

\section{Abbreviations:}

AzMZ - Azov museum-reserve, Azov, Russia;

AstrMZ - Astrakhan state museum-reserve, Astrakhan', Russia;

GIN - Geological institute RAS, Moscow, Russia; PIN - Paleontological institute RAS, Moscow, Russia;

ROMK - Rostov local museum, Rostov-on-Don, Russia;

SSC - Southern Scientific Centre RAS, Rostovon-Don, Russia.

\section{Description and comparison}

The interalveolar hollow in front is well defined, appears relatively narrow and deep, distally not widened, unlike those on the skulls of adult and juvenile individuals of the genus Elephas (Palaeoloxodon) (Dubrovo, 1960; Palombo \& Ferretti, 2005). It has approximately equal width throughout the observed length. Premaxillary bones in their preserved upper half do not expand rostrally, which also distinguishes the described specimen from skulls of straight-tusked or forest elephants. The bony palate is relatively narrow. It is comparable to the width of the tooth crown. The posterior edge of the palate is situated behind the posterior edge of $\mathrm{dP} 4$ and forms a wide U-shaped notch. Fragments of the tusk in the aboral part of the alveoli make it possible to estimate its diameter (Tab. 1). The tusk is slightly flattened from the sides. The coefficient of its flatness is 0.86 .

The upper teeth $\mathrm{dP} 4$ are relatively wide. The ratio of the width of the crown to its length is about $49.1 \%$ (left), 46.7\% (right). The enamel is slightly folded. The incipient wear figures on the occlusal surface of trinomial plate is of antiquoid type $(\bullet-\bullet)$. Median sinuses are not expressed. The teeth consists of 11 enamel plates in the right one, and 10.5 plates in the left (including additional plate), plus anterior and posterior talons (= platelets) (Tab. 2). The estimated full number of plates in these teeth is based on the preservation of the anterior main root, which is displaced laterally. Its front edge, which is the base for the first plate, has been preserved. There are two plates in addition to a talon at the main root. The additional enamel plate is present on the buccal surface of the right tooth between the third and fourth plates, reaching the mid-width of the crown. The dP4 belong to the wear stage 4-5 (according to Garutt \& Foronova, 1976). Traces of the alveoli of the tooth previous replacement are absent. Posterior talons are not affected by wear.

The incomplete unerupted tooth M1 is located in the upper jaw. A height of the 4th dental plate is 116.1 $\mathrm{mm}$, the length of single plate, about $12.7 \mathrm{~mm}$. The lamellar frequency at $5 \mathrm{~cm}$ is 4.1 . The enamel thickness is $2.2 \mathrm{~mm}$.

The degree of teeth wear corresponds to the XI age stage of African elephants. The estimated age of the studied individual corresponds to 15 years (according to Laws, 1966), or 13-14 (by Lee et al., 2012).

In the length of the crown and the number of plates, the dP4 teeth from Kagalnik are similar to those of the early Middle Pleistocene $M$. trogontherii of Süssenborn (Guenther, 1969). Teeth of the described specimen have somewhat higher lamellar frequency in comparison to the sample from Süssenborn (Figs 3, 4). 
Table 2. Measurements of dP4 of Mammuthus trogontherii from Kagalnik settlement (collection No SSC RAS K-1; Zeleniy locality; North-Eastern Sea of Azov area, Russia) with comparison to dP4 of M. trogontherii from Süssenborn (Germany; by Guenter, 1969, Tab. 6, Abb. 1, 3, 4, 6).

\begin{tabular}{lcc|c}
\hline Measurements dP4, mm & left & right & Süssenborn \\
\hline Tooth formula & ${ }^{\mathrm{t} 1} 2 \frac{1}{2} 7 \mathrm{t}$ & ${ }^{\mathrm{t} 1} 10 \mathrm{t}$ & \\
Number of plates (without talons) & 10.5 & & 11 \\
Crown length, mm & 142.4 & 140.8 & $8-(9.4)-11$ \\
Crown width, mm & 69.9 & 65.7 & $110-(143.2)-165$ \\
Lamellar frequency at $5 / 10 \mathrm{~cm}$ & $4.4 / 8.8$ & $4.25 / 8.5$ & $50-(57)-70$ \\
Length of single plate, $\mathrm{mm}$ & 11.4 & 12.2 & $7-8^{*}$ \\
Enamel thickness, mm & $1.6-(1.8)-2.1$ & $1.5-(1.6)-1.9$ & $10.25-(11.9)-14.5$ \\
\hline
\end{tabular}

* - by Dubrovo, 2001, tab. 1a. — wearing part of the crown.

From dP4 of $M$. cf. intermedius from the lower Volga region near Astrakhan (terminal Middle Pleistocene - early Late Pleistocene; Russia; coll. AstrMZ No. PL-129), which has a similar lamellar frequency, the specimen from Kagalnik differs in larger crown size and enamel thickness (Figs 3, 4).

Showing similar values of enamel thickness, the studied specimen has a higher lamellar frequency and larger crown size of dP4 and M1 than Early Pleistocene forms of Archidiskodon (Figs 2, 3; Baigusheva et al., $2016 \mathrm{a}, \mathrm{b})$. The crown of dP4 in the described specimen is somewhat narrower than in southern elephants from the collections of AzMZ, GIN, PIN, ROMK. The crown $\mathrm{W} / \mathrm{L}$ ratio ranges as $52.8-53.2(\mathrm{n}=2)$ in $A$. meridionalis gromovi, and as 45.3-(50.5)-5.4 $(\mathrm{n}=6)$ in A. m. tamanensis.

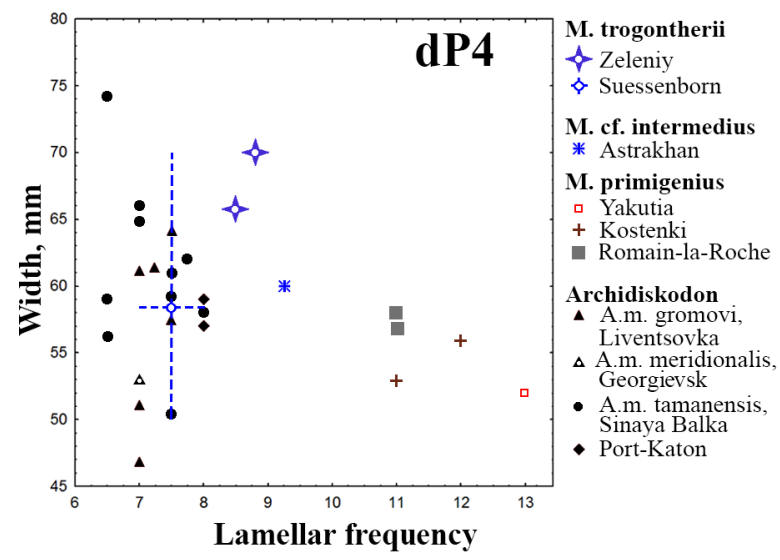

Fig. 3. Scatter diagram of crown width against lamellar frequency of dP4 of Mammuthus trogontherii from Kagalnik (Zeleniy locality) in comparison with some findings of the same teeth of $M$. trogontherii, $M$. cf. intermedius, M. primigenius and Archidiskodon from different European localities. Data from Guenther, 1969, Dubrovo, 2001 (Süssenborn), Dubrovo, 2001 (Yakutia and Romain-la-Roche), Maschenko, 2002 (Kostenki), and own measurements of the specimens from Zeleniy, Astrakhan, Liventsovka, Georgievsk, Sinaya Balka and Port-Katon. For the sample from Süssenborn the variability ranges of dental characters are indicate by dashed line.
Variables of dP4 No. SSC K-1 exceed the variability observed for this tooth type in the Late Pleistocene M. primigenius from Eastern Siberia and Eastern Europe, from sites Kostyonki, Eliseevici, Sevsk, Bolshoy Lyakhovsky Island (Dubrovo, 2001; Maschenko, 2002; Maschenko et al., 2005, 2006). The teeth of woolly mammoths are smaller, have a noticeably higher lamellar frequency, a longer length of a single plate, and a smaller enamel thickness (Figs 3, 4).

\section{Discussion}

Teeth of early generations in elephants are traditionally considered to be poorly diagnosed. The accumulation of representative dental collections, however,

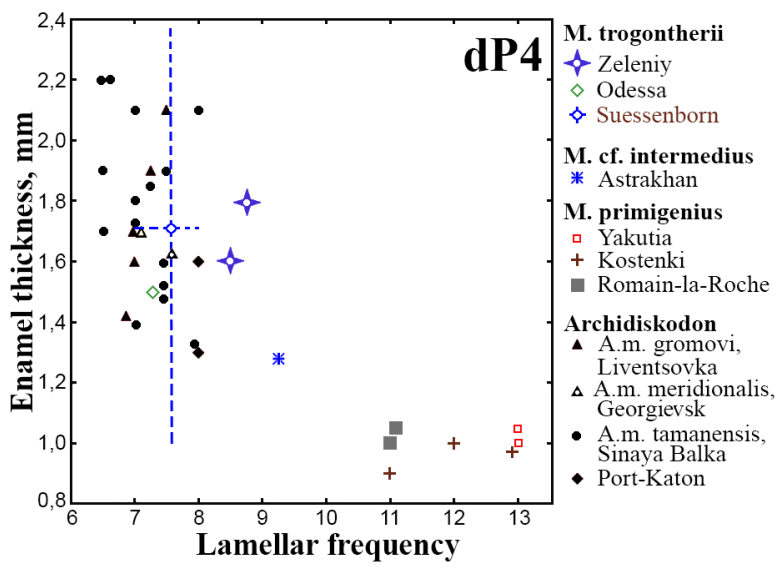

Fig. 4. Scatter diagram of enamel thickness against lamellar frequency of dP4 of Mammuthus trogontherii from Kagalnik (Zeleniy locality) in comparison with specimens of the same teeth in M. trogontherii, $M$. cf. intermedius, M. primigenius, and Archidiskodon from different European localities. Data from Guenther, 1969, Dubrovo, 2001 (Süssenborn), Yatsko, 1948 (Odessa), Dubrovo, 2001 (Yakutia and Romain-laRoche), Maschenko, 2002 (Kostenki), and original measurements of the specimens from Zeleniy, Astrakhan, Liventsovka, Georgievsk, Sinaya Balka and Port-Katon. For the sample from Süssenborn the variability ranges of dental characters are indicate by dashed line. 
makes it possible to use the teeth of early ontogenetic types for their taxonomic attribution in cases when other diagnostic characters are missing. Based on the material from a number of Early Pleistocene localities from the south of Eastern Europe (variables of the dP4/ $\mathrm{dp} 4, \mathrm{M} 1 / \mathrm{m} 1$ and, partly, dP3/dp3), it is demonstrated a possibility to differentiate between forms of mammuthoid elephants, even at the level of chrono-subspecies of Archidiskodon meridionalis (Nesti, 1825) (Baigusheva et al., 2016a, b).

Unfortunately, there are very few published accounts of juvenile teeth of $M$. trogontherii and $M$. primigenius with given measurements (for example, Guenther, 1969; Dubrovo, 2001; Maschenko, 2002; Maschenko et al., 2006). Though the studied samples of woolly mammoths are relatively numerous, the published samples of juvenile teeth are not representative. This hampers a detailed comparison of the described form with latest mammoths. Nevertheless, the available data permits to differentiate dP4 of $M$. trogontherii from both Early Pleistocene southern elephants, and from other species of the genus Mammuthus too.

\section{Results}

The described record of the fragmentary skull of a young elephant from the site of Kagalnik in the Lower Don River area adds to the knowledge of large size throgontherine elephants, previously known in this region by two nearly complete adult skeletons. $M$. trogontherii is the characteristic element in the Eurasian mammal fauna of early Middle Pleistocene.

The variables of $\mathrm{dP} 4$ in this specimen make it possible to distinguish it from the juvenile teeth of the Early Pleistocene Archidiskodon by averagely larger crown size and higher lamellar frequency. From late Middle and Late Pleistocene forms of the genus Mammuthus it differs by larger crown dimensions, lower lamellar frequency, and by thicker enamel. Dental characters of early Middle Pleistocene elephants from the northeast of the Sea of Azov are similar to variables published for $M$. trogontherii from Süssenborn. Its parameters fall within the uppermost limits of the variability range of the sample from Germany. The Kagalnik specimen is different from the early Middle Pleistocene trogontheriine elephants of Western Europe in larger size and slightly higher values of lamellar frequency.

The structure of the premaxillary bones, as well as the crown variables in addition to the absence of median sinuses in the wear pattern on the occlusal surface, distinguish a fragmentary skull from Kagalnik from the straight-tusked elephants Elephas (Palaeoloxodon) cooccuring with mamuthoid elephants in the Middle Pleistocene of Eurasia.

Acknowledgements. We thank V.P. Kovalenko, who promoted the transfer of the skull to the Museum of Cossacks, Ethnography and Culture of the Sea of Azov Region of the Southern Scientific Center of the
Russian Academy of Sciences (Kagalnik, Azov district, Rostov Region, Russia). We also thank Dr. E.N. Maschenko and the editors for the valuable remarks, which helped us to improve the article. We are grateful to colleagues from Azov Museum-Reserve (G.I. Timonina, S.V. Semenova), Astrakhan State MuseumReserve (M.V. Golovachev), Stavropol State MuseumReserve (A.K. Shvyreva) and Paleontological Institute RAS (E.N. Maschenko) for the possibility to work with comparative collections. The study was supported by the Russian Science Foundation, project no. 16-1710170.

\section{References}

Baigusheva V.S., Titov V.V. \& Foronova I.V. 2016a. [Peculiarities of teeth of early generations of elephants of genus Archidiskodon (Mammalia, Elephantidae) from the Early Pleistocene of the south of Eastern Europe] // Nauka Yuga Rossii (Vestnik Yuzhnogo nauchnogo centra). Vol.12. No.3. P.67-88 [in Russian].

Baigusheva V.S., Titov V.V. \& Foronova I.V. 2016b. Teeth of early generations of elephant Archidiskodon meridionalis tamanensis (Mammalia, Elephantidae) from Sea of Azov Region (Russia) // Quaternary International. Vol.420. P.306-318.

Baygusheva V.S. \& Garutt V.E. 1987. [Skeleton of steppe elephant Archidiskodon trogontherii (Pohlig, 1885) from the North Eastern Azov region] // Proceedings of Zoological Institute of the USSR Academy of Sciences. Vol.168. P.21-37 [in Russian].

Baygusheva V.S. \& Timonina G.I. 2001. [About excavations of skeleton of steppe or trogontherii elephant Mammuthus trogontherii (Pohlig, 1885) near Azov city in 1999 // Kiyashko V.Ya. (ed.). Istoriko-arkheologicheskie issledovaniya v Azove i na Nizhnem Donu v 1999-2000. Azov. Vol.17. P.27-38 [in Russian].

Baygusheva V.S., Titov V.V. \& Timonina G.I. 2012. Two skeletons of Mammuthus trogontherii from the Sea of Azov Region // Quaternary International. Vol.276-277. P.242-252.

Dubrovo I.A. 1960. [Ancient elephants of the SSSR] // Trudy Paleontologicheskogo instituta AN SSSR. No.85. 78 p. [In Russian]

Dubrovo I.A. 2001. Remains of Elephantidae from the Lower Pleistocene site of Untermassfeld // Kahlke R.-D. (ed.). Das Pleistozän von Untermaßfeld bei Meiningen (Thüringen). Teil 2. Monographien des Römisch-Germanischen Zentralmuseums Mainz, 40. Mainz: Habelt. P.589-605.

Frolov P.D. \& Kurshakov S.V. 2015. The early Middle Pleistocene freshwater fauna from the North-East Sea of Azov region: taxonomic and paleoecological analysis // Vestnik Yuzhnogo nauchnogo centra. Vol.1. No.4. P.4354 [in Russian, with English summary]

Garutt V.E. 1977. [Dentition of elephants in ontogenesis and philogenesis] // Proceedings of Zoological Institute of the USSR Academy of Sciences. No.73. P.3-36 [in Russian].

Garutt V.E. \& Foronova I.V. 1976. [Research on the teeth of extant elephants: Methodological Recommendations]. 
Novosibirsk: Institute of Geology and Geophysics. 36 p. [In Russian]

Guenther E.W. 1969. Die Elefantenmolaren aus den Kiesen von Süssenborn bei Weimar // Palaontologische Abhandlungen. Bd.A3. S.711-734.

Jachmann H. 1988. Estimating age in African elephants: a revision of Laws' molar evaluation technique // African Journal of Ecology. Vol.26. P.51-56.

Laws R.M. 1966. Age criteria for the African elephant // East African Wildlife Journal. Vol.4. P.1-37.

Lebedeva N.A. 1972. [Anthropogene of Priazovie]. Moscow: Nauka. 106 p. [In Russian]

Lee P.C., Sayialel S., Lindsay W.K. \& Moss C.J. 2012. African elephant age determination from teeth: validation from known individuals // African Journal of Ecology. Vol.50. P.9-20.

Lister A.M. \& Stuart A.J. 2010. The West Runton mammoth (Mammuthus trogontherii) and its evolutionary significance // Quaternary International. Vol. 228. P.180-209.

Maglio V.J. 1973. Origin and evolution of the Elephantidae // Transactions of the American Philosophical Society. Vol.63. 149 p.

Maschenko E.N. 2002. Individual development, biology and evolution of the woolly mammoth Mammuthus primigenius (Blumenbach, 1799) // Cranium. Vol.19. No.1. $120 \mathrm{p}$.

Maschenko E.N., Gablina S.S., Tesakov A.S. \& Simakova A.N. 2006. The Sevsk wooly mammoth (Mammuthus primigenius) site in Russia: taphonomic, biological and behavioral interpretations // Quaternary International. Vol.142-143. P.147-165.

Maschenko E.N., Tikhonov A.N. \& MacPhee R.D.E. 2005 Mammoth calf from Bolshoi Lyakhovskii Island (New
Siberian Islands, Arctic Siberia // Russian Journal of Theriology. Vol.4. No.1. P.79-88.

Palombo M.R. \& Ferretti M.P. 2005. Elephant fossil record from Italy: knowledge, problems, and perspectives // Quaternary International. Vol.126-128. P.107-136.

Pawlowska K., Greenfield H. \& Czubla P. 2014. 'Steppe' mammoth (Mammuthus trogontherii) remains in their geological and cultural context from Belchatów (Poland): A consideration of human exploitation in the Middle Pleistocene // Quaternary International. Vol.326327. P.448-468.

Quaternary stratigraphy and paleontology of the southern Russia: connections between Europe, Africa and Asia. Programme and guidebook of excursions of the International INQUA-SEQS Conference (Rostov-on-Don, June 21-26, 2010). 2010. Rostov-on-Don. 52 p.

Tesakov A.S., Dodonov A.E., Titov V.V. \& Trubikhin V.M. 2007. Plio-Pleistocene geological record and small mammal faunas, eastern shore of the Azov Sea, southern European Russia// Quaternary International. Vol.160. P.57-69.

Tong H.-W. 2012. New remains of Mammuthus trogontherii from the Early Pleistocene Nihewan beds at Shanshenmiaozui, Hebei // Quaternary International. Vol.255. P.217-230.

Tong H.-W. \& Chen X. 2016. On newborn calf skulls of Early Pleistocene Mammuthus trogontherii from Shanshenmiaozui in Nihewan Basin, China // Quaternary International. Vol.406. P.57-69.

Yatsko I.Ya. 1948. [The skeleton of Elephas wüsti M. Pawl. from terrace deposits of Khadzhibeyskiy estuary near Odessa] // Trudy Odessa State University. Vol.2. No.2 (54). P.49-84 [in Russian]. 